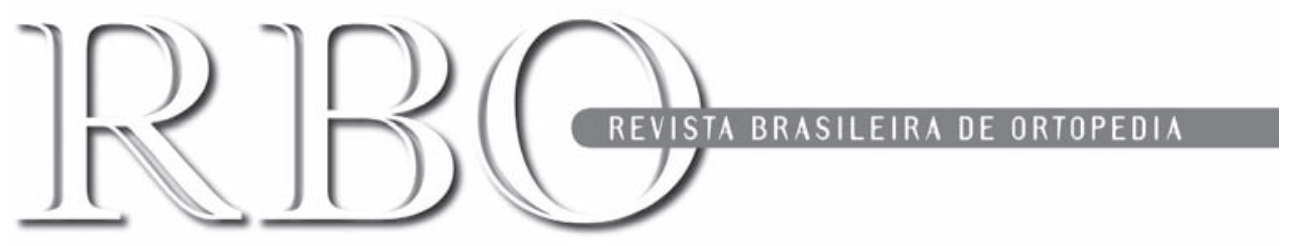

\title{
Editorial
}

\section{Conflito de interesse}

A ortopedia é uma especialidade que tem uma evolução contínua e constante, especialmente no que se refere ao desenvolvimento de materiais.

Graças ao constante investimento na importação de novos instrumentais, na manutenção de programas de educação médica, no patrocínio de congressos e de visitas de especialistas estrangeiros, no envio de especialistas brasileiros para o exterior, as empresas de material ortopédico e a indústria farmacêutica têm dado uma contribuição fundamental para o desenvolvimento e atualização da ortopedia brasileira.

Negar estes fatos seria infantil e hipócrita.

O relacionamento destas empresas com os seus clientes é baseado nos princípios que interessam aos seus sistemas de marketing e independem da vontade ou da interferência da Sociedade Brasileira de Ortopedia e Traumatologia - SBOT ou de qualquer comissão de ética.

Oferecer brindes, viagens ou jantares e patrocinar congressos são formas que os profissionais destas empresas têm para atrair a atenção do médico para os seus produtos. São hábeis em utilizar estes atrativos e sabem que só o médico pode veicular os seus produtos; pois, sem a indicação ou a prescrição médica, todo o esforço de comercialização seria inútil.

0 médico é regido por um sistema ético escrito, que é o nosso código de ética, do qual nos orgulhamos muito, e por um código íntimo, que é muito mais importante.

Ao tratarmos de um paciente, a relação de responsabilidade é muito mais profunda do que aquilo que o código de ética estabelece; um erro, mesmo que involuntário, irá nos marcar intimamente por toda a vida.

A nossa ética difere profundamente da ética da indústria de materiais e da indústria farmacêutica; não é nem melhor nem pior, é diferente.

A nossa relação com as indústrias é pessoal, baseada nos princípios de nossa formação e respeitando o nosso código de ética, que é pouco atualizado neste aspecto. Não há regras atuais claras que estabeleçam o que é lícito ou ilícito na relação profissional entre o médico e as indústrias de material cirúrgico e farmacêutico.

A American Academy of Orthopaedic Surgeons - AAOS estabeleceu recentemente um código muito rígido, com 17 capítulos, para mediar a relação entre as empresas e os médicos, ao qual chamou de: "Código de ética médica e profissional para cirurgiões ortopedistas".

Este código pretende estabelecer regras no relacionamento entre os ortopedistas e as indústrias no que se refere a consultorias, desenvolvimento de produtos, congressos e outros pontos. Este mesmo código impõe que, nas apresentações em congressos e nas publicações científicas, os autores declarem se há conflito de interesse.

Há conflito de interesse quando verifica-se uma situação na qual o médico ou alguém próximo de sua família tem alguma relação de natureza financeira com a empresa da qual o produto é objeto do trabalho apresentado.

A Agência Nacional de Vigilância Sanitária - ANVISA tem um modelo escrito sobre esta relação, e o Conselho Federal de Medicina (CFM), na resolução 1595/2000, determina a obrigatoriedade da declaração do conflito de interesse no artigo 2, que assim define:

"Determinar que os médicos, ao proferir palestras ou escrever artigos divulgando ou promovendo produtos farmacêuticos ou equipamentos para uso na medicina, declarem os agentes financeiros que patrocinam suas pesquisas e/ou suas apresentações (...)".

No que se refere às publicações científicas, interessa-nos informar esta relação e deixar ao leitor o julgamento sobre a influência da relação dos autores com a empresa que produz ou comercializa o produto objeto da publicação e se isso interfere ou não na conclusão do trabalho em questão.

Na Revista Brasileira de Ortopedia, solicitamos que os autores declarem se há ou não conflito de interesse no trabalho que esta sendo publicado.

Acreditamos que é mais uma informação que, aliada à titulação dos autores e à origem do trabalho, qualificará o tema a ser consultado.

Procedendo dessa forma, estamos apenas seguindo uma determinação do CFM e uma tendência mundial de informarmos o leitor sobre as origens do trabalho que será lido e interpretado, fornecendo subsídios para a sua aplicabilidade na prática profissional. 